\title{
İşlevsel Halk Bilimi Kuramı Bağlamında İzmir Aliağa Yöresi Karaköy Köyü Mânileria $^{a}$
}

\author{
Necati Özcan ${ }^{\mathrm{b}, \mathrm{c}}$
}

Özet

Bağlam merkezli halk bilimi kuramlarından işlevsel halk bilimi kuramı halk yaratmalarını icra veya bağlam ekseninde araştırır ve inceler. İşlevsel yaklaşıma göre her icranın, söylemin veya dinlemenin ortaya çıktığı bağlamda bir nedeni vardır. Folklor unsurunun insan yaşamındaki rolünü anlamak önemlidir. Türk kültür coğrafyasında yaygın ve önemli bir yere sahip mâniler, halk yaşantısını içerisinde barındıran canlı bir halk edebiyatı türüdür. Halkın yaşantısında duygu, düşünce ve hayalleri dile getirmesi, eğitici olması, sosyalleşmeyi sağlaması, toplumun kurumlarına destek vermesi, kültürün nesillere aktarılması gibi birçok işleve sahiptir. Bu araştırmada nitel araştırma modellerinden alan araştırması yöntemiyle çalışılmış, kaynak kişilerle yapılan görüşme ve mülakatlarla veriler toplanmıştır. İzmir Aliağa Karaköy Köyü'nden derlenen mâniler, bağlam merkezli halk bilimi kuramlarından işlevsel halk bilimi kuramı çerçevesinde değerlendirilmiş, William $R$. Bascom'un halk bilimi unsurlarının işlevlerine göre örneklendirilmiştir. Aliağa Karaköy yöresi mânilerinin geçmişten bugüne yaşamda önemli yer tuttuğu ancak kent kültürü etkisi, dijitalleşme ve sosyoekonomik sebeplerle sosyal hayatın değiştiği, dolayısıyla mâni söyleme kültürünün yaşam şartlarının değişmesiyle gitgide zayıfladı̆̆ı tespit edilmiştir.
Anahtar Kelimeler

Aliağa

Karaköy

mâni

işlev

Makale Hakkında

Geliş Tarihi: 05.03.2021

Kabul Tarihi: 24.09.2021

Doi: $10.18026 /$ cbayarsos. 892020

\section{The Turkish Poems of Karaköy Village, Aliağa, İzmir in the Context of Functional Folklore Theories}

\begin{abstract}
Functional folklore theory, which is one of the context-centred folklore theories, investigates and examines folk creations in terms of performance or context. According to the functional approach, every performance, discourse or listening has a reason in the context in which it occurs. It is important to understand the role of folklore in human life. Turkısh poems, which have a widespread and important place in the oral culture region, is a living folk literature type that includes folklife. They have many functions such as expressing feelings, thoughts and dreams in the community's life, being educational, providing socialization, supporting the institutions of the society, and transferring the culture to generations. In this study, the data was gathered by means of the interview method, which is one of the qualitative research methods, by doing zone research in Karaköy village, in Aliağa, İzmir. The compiled Turkish traditional folk poems (mâni) were evaluated within the framework of functional folklore theory of context-centred folklore theories and exemplified according to the functions of folklore elements of William R. Bascom.
\end{abstract}

Keywords

Aliağa

Karaköy

mâni

function

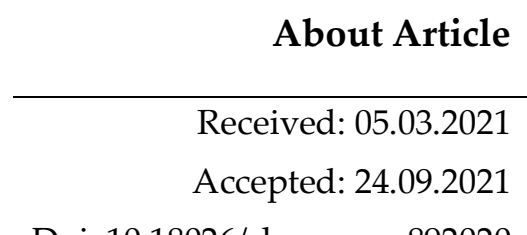

Doi: $10.18026 /$ cbayarsos.892020

\footnotetext{
a 2. Uluslararası Motif Genç Halkbilimciler ve Türk Dünyası Kongresi'nde sözlü bildiri olarak sunulmuştur.

b İletişim Yazarı: nctzcn@gmail.com

c Yüksek Lisans Öğrencisi, Bayburt Üniversitesi Lisansüstü Eğitim Enstitüsü Türk Dili ve Edebiyatı ABD, ORCID ID: 0000-0002-1524-0600
} 


\section{Giriş}

İnsanların ve halkların ortak yaşam unsurları kültürü oluşturur. Sapir'e göre “Sosyal miras ve gelenekler bütünü olarak kültür, varlığımızın yapısını (ilişkilerini) belirleyen, sosyal bir süreçle öğrendiğimiz uygulama ve inançların, maddi ve manevi öğelerin birliğidir." Taylor'a göre ise "Kültür ya da uygarlık, bir toplumun üyesi olarak, insanoğlunun öğrendiği (kazandığı) bilgi, sanat, gelenek-görenek ve benzeri yetenek, beceri ve alışkanlıkları içine alan karmaşık bir bütündür." (Güvenç, 2002, s. 101-102). Bu bütünlük çerçevesinde halk yaşamında belirgin olan anonim halk edebiyatı yaratmaları içerisinde yer alan yaygın türlerden birisi de mânilerdir.

Geçmişten bugüne halkın yaşantısını içerisinde barındırarak bugünlere gelmiş olan mâniler, yaşamın içerisinde canlı bir edebî tür olarak yer almıştır. Mâniler, sözlü kültür çevresinde gelişen halk edebiyatı türleri arasında tercih edilen bir şiir türü olarak halk yaşantısında kıymetli bir yer edinmiştir. İnsanların zihninde ve kalbinde var olan aşk, hasret, gurbet, sevgi, nefret, hüzün vb. birçok duyguyu dile getiren mânilerde bununla birlikte insanların ve toplumların hayatlarını idame ettirirken ortaya koydukları eylemleri görürüz. Mâniler; tarlayı işleme, hasatın kaldırılması, imeceyle iş tutma; Nevruz, Hıdırellez, bayramlar, düğünler, sünnet törenleri gibi önemli gün ve kutlamalarla ortaya çıan halk kültürünün geçmişten bugüne taşıyıcısı olma özelliğiyle de folklor için önemli bir kaynak teşkil ederler. (Elçin, 1997, s. 324)

Geniş bir coğrafyada var olan Türk dili ve kültürünün sözlü edebiyat geleneğinde önemli bir yeri olan mâniler Türk dünyasının bazı bölgelerinde farklı adlarla ifade edilir. (Boratav, 1995, s. 171) Anadolu'da: Mana-deyişleme (Denizli), me'ani (Urfa), hoyrat (Diyarbakır), meni (Kars), ficek (Erzincan), karşıberi (Doğu Karadeniz); Anadolu dışında: beyati mâni-meni-mahnımahna (Azerbaycan), hoyrat (Irak), çing-çinile-çır (Kırım), aşule (Özbekistan), aytıpa-tört sap (Kırgızistan), kayım ülenk (Kazakistan), törtlik (Uygur), martifal (Pirizren) vb. isimler verilmektedir (Şimşek, 2015, s. 60).

Mâniler, genellikle yedi heceli olup dört dizeden oluşurlar. Birinci, ikinci ve dördüncü dizeleri uyaklı üçüncü dize ise serbest olacak biçimde (aaxa) söylenirler. Bu mâniler "düz mâni" olarak adlandırılır. Birinci dizesinin hece sayısı yediden az olan mânilere "kesik mâni" veya -bu türün cinaslı söylenişleri yaygın olduğu için- "cinaslı mâni" denir. Dört dizeli düz mâniye aynı uyakta başka dizeler eklenerek söylenen mâniye ise "artık mâni" (aaxaxa...) denilirken iki kişinin karşılıklı söylediği mânilere ise deyiş (karşılıklı mâni) adı verilir (Dilçin, 1995, s. 279289).

Mâniler, ahenkli bir söyleyiş özelliği taşıyan kısa şiirlerdir. Söylemesi kolay ve eğlendirici oldukları için olsa gerek anonim Türk halk şiirinin yaygın ve çok kullanılan şiir türlerindendir. Mânilerde her bir dizenin kendi içerisinde, mâninin bütünlüğünde bir anlamı ve estetik değeri vardır. (Karabaş, 1981, s. 56-61). Dört mısralık düz mâni biçiminin daha çok kullanıldığı mânilerin mısraları arasında anlam bütünlüğü olmakla birlikte asıl anlatılmak istenen duygu ve düşünceler son iki dizede söylenir. Mâni söyleyicileri genellikle "mânici", "mahnıcı", "mâni yakıcı", "mâni düzücü" ve "mâni atıcı" gibi adlarla anılırlar (Ekici, 2002, s. 12).

Mâniler; duygu ve düşünceleri ifade etme aracı olması, toplumsal birlikteliğe, paylaşıma katkı suması, sosyal dayanışmayı artırması; örf, adet, geleneklerin ve kültürün sözlü yolla aktarması, insanlara sosyalleşme imkânı tanıması gibi yaşamın birçok yönüne hitap etmesi bakımından işlevsel bir anonim halk edebiyatı türüdür. Artun da mânilerin örf, adet ve 
geleneklerin kuşaktan kuşağa aktarımı sağlamak yönüyle işlevsel olduğunu belirtir (Artun, 2006, s. 11).

Bu makalede İzmir Aliağa Karaköy yöresinden derlenen mâniler, halk bilimi bağlam ve icra merkezli halk bilimi kuramlarından "işlevsel halk bilimi kuramı" çerçevesinde değerlendirilecektir.

\section{Yöntem}

Araştırmada nitel araştırma modellerinden alan araştırması yöntemi kullanılmıştır. Araştırma sürecinde ilk olarak saha araştırmasında kullanılacak olan mülakat formu hazırlanmıştır. Sahada yaşayan yerli ahaliden mâni bilen kaynak kişiler belirlenmiş, nitel araştırma veri toplama araçları mülakat ve görüşme yöntemiyle üç kaynak kişiden altmış mâni derlenmiştir. Kaynak kişilerden derlenen mâniler işlevsel kuram çerçevesinde değerlendirilmiştir. Makale içerisinde kaynak kişiler "KK" şeklinde numaralandırılmıştır. Kaynak kişilere ait bilgiler kaynakça bölümünde verilmiştir. Araştırmanın teorik kısımlarında alan-yazın taraması, kaynak araştırması yönteminden yararlanılmıştır.

\section{Aliağa Karaköy Yöresinde Mâni Söyleme Geleneği}

Alan araştırmasının yapıldığı Karaköy köyü, İzmir'e 83 km, Aliağa ilçesine 15 km mesafede bir tepe köyüdür. 2019 verilerine göre köyün nüfusu 182' dir. Köyün yerli halkı geçimini tarım ve hayvancılıkla sağlamakla birlikte köyün Aliağa merkeze yakınlığı dolayısıyla genç nüfus Aliağa'da yer alan PETKIM, TÜPRAŞ, SOCAR gibi petrol rafinerilerinde vb. işletmelerde çalışarak geçimini sağlamaktadır. Akdeniz ikliminin hâkim olduğu yörede yazlar sıcak, kışlar ise 1 lık ve yağışlıdır. Aliağa ilçesinde tarım ürünlerinden pamuk, zeytin, mısır ve üzüm yetiştiriciliği önemli yer tutmaktadır. Tarım ürünlerinin önemli bir bölümünü zeytin yetiştiriciliği oluşturmaktadır.

Köyün şehir kültürüne yakın bir coğrafyada yer alması doğal olarak şehirleşmeden etkilenmelerine sebep olmuş, televizyon, internet, bilgisayar gibi iletişim araçlarının günlük yaşamda yer alması köyde halk kültürünün hızlı değişiminde etkili olmuştur. Köyde mâni söyleme geleneği; "mâni söyleme”, "türkü söyleme” şeklinde ifade edilmektedir.

Mâni kültürünün eskiden çok yaygın olduğu öğrenilen yörede evlerdeki misafir toplantılarında dahi neşelenince içten gelen bir coşkuyla mâni söylendiği öğrenilmiştir. Mânileri daha çok dili ve hafızası kuvvetli kişilerin söylediği ve nesilden nesle aktardığı kaynak kişilerden kaydedilen bilgiler arasındadır. Mâni söyleyen kaynak kişilerin annelerinin de mâni söyledikleri dikkat çekicidir. Hafızası iyi olan annelerin mâni söyleme kabiliyetlerinin çocuklarına geçtiği, kaynak kişilerin bu yeteneklerinin sosyal çevre etkisiyle de daha iyi seviyeye ulaştığı ve sonrasında toplum tarafından takdir gören bu davranışın ilgiyle ileri seviyeye taşındığı söylenebilir. Bu noktada kültürün eğitici işlevine de dikkat çekmek yerinde olacaktır.

Kaynak kişilerden edinilen bilgiye göre mânilerin yoğun biçimde söylendiği kız görme, kız isteme, gelin alma, nişan merasimi, düğün gibi evlenme törenleri kent kültürüyle birlikte dijitalleşme ve sosyoekonomik sebeplerle eskisi gibi yapılmamaktadır. Dolayısıyla mâni söyleme kültürünün yaşam şartlarının değişmesiyle gitgide zayıfladığı tespit edilmiştir. Mâni söyleme uygulamasının daha çok yaşlılar tarafından bilindiği, bu yüzden geleneğin kısmen sürdürüldüğü öğrenilmiştir. Daha çok kadınlar tarafından söylenen mâniler ezberden okunmakla birlikte doğaçlama olarak da söylenmektedir. Yöre kültüründe mâni söyleme 
uygulamasının önceki zamanlarda daha çok evlenme merasimleri esnasında toplanan kadınlarca darbuka ve leğen çalınarak söylendiği öğrenilmiştir. Kaynak kişilerin söyledikleri mânileri türkülerle karıştırdıkları, ezgiyle duydukları metinleri daha iyi hatırladıkları gözlenmiştir. Bununla birlikte daha çok zeytin toplamak amaciyla düzenlenen imece yardımlaşma toplantılarında, kadınların yer aldığı ev toplantılarında da mâni söyleme eğlencesi kısmen yaşlı insanlar tarafından uygulanmakla birlikte mâni söyleme etkinliklerinin canlılığının ve yerinin yöre kültüründe gün geçtikçe azaldığ Günümüzde yörede söylenen mâni türleri arasında evlenme törenleri mânileri, imece toplantıları (zeytin toplama) ve sevda mânilerinin söylenegeldiğini bunların içerisinde en yaygın olanların ise sevda mânileri olduğunu söyleyebiliriz.

İzmir Aliağa Karaköy yöresinden derlenen mânilerin halk bilimi bağlam ve icra merkezli halk bilimi kuramlarından "işlevsel halk bilimi kuramı" çerçevesinde değerlendireceği bu makalede bulgular bölümüne geçmeden önce işlevsel halk bilimi kuramı hakkında bilgi vermek yararlı olacaktır.

\section{İşlevsel Halk Bilimi Kuramı}

Halkbilimi kuram ve yöntemlerinden biri olan İşlevsel kuram, halk edebiyatı yaratmalarını bağlam (sosyal çevre) veya icra (performans) merkezli olarak araştırır ve inceler. Halk edebiyatı yaratmalarını inceleyen antropologlar tarafından geliştirilen "Antropolojik Yöntem" olarak da bilinen işlevsel yöntem, halkbilimi çalışmalarını farklı yöne taşıyan önemli bir yaklaşımdır (Ekici vd., 2018, s. 87).

"İşlevsel yöntemin hareket noktası halk bilgisi ürünlerinin metinleri değil, bu metinlerin oluşturuldukları, yaratıldıkları ve nakledildikleri bağlamdır." (Ekici, 2004, s. 119). İşte bu bağlam noktasında işlevsel kuramcılar şu sorular üzerinde yoğunlaşırlar: Bir halk edebiyatı yaratmasının anlatılması veya söylenmesinin nedeni nedir? Anlatıcı ve icracının onu yaratma, aktarma ve kullanma nedenleri nelerdir? Dinleyicilerin o yaratmayı dinleme, anlama ve kullanma nedenleri nelerdir? Yaratılan metnin veya yapılan uygulamanın ortaya çıkması ve icrasında başka etkenler var mıdır? gibi sorular işlevsel yöntemin temel sorunlarını oluşturmaktadır (Ekici vd., 2018, s. 87).

İşlevsel kuramclara göre, folklor unsurunun anlatan, dinleyen üzerindeki etkisi ile insan yaşamındaki rolünü anlamak önemlidir ve folklorun farklı topluluklardaki uygulamalarını bilmek gerekir çünkü bir folklor unsuru birden fazla işleve sahip olabilir. Meselâ mitler, türküler, atasözleri gibi folklorik unsurlar farklı toplumlarda icra edildiği bağlama bağlı olarak farklı işlevlerde farklı uygulama biçimleriyle karşımıza çıkabilir. Bir folklor unsuru birden fazla işlevi yerine getirebilir. Ekici'ye göre, "İşlev konusu; halk edebiyatı metinlerindeki değişkenlik, hacim ve içerik farklılaşması gibi sorunları çözmede araştırmacılara yardımcı olur." (Ekici vd., 2018, s. 87).

İşlevsel kuramın kurucularından Bronislaw Kasper Malinowski, kültürü “Aletlerden ve tüketim mallarından, çeşitli toplumsal gruplaşmalar için yapılan anayasal belgelerden, insana özgü düşünce ve becerilerden, inanç ve becerilerden oluşan bütünsel bir toplam." olarak tanımlar (Çobanoğlu, 2019, s. 252). Malinowski'ye göre her kültürel yaratmanın temelinde insanın; beslenme, üreme, bedensel rahatlıklar, güvenlik, hareket, büyüme, metabolizma ve sağlık gibi temel ihtiyaçları yer alır. İnsan ve toplumlar her şeyden önce organizmanın ihtiyaçlarını karşılamak zorunda hissederler. Beslenmek, barınmak, giyinmek, korunmak, yaşamlarını idame ettirmek için birtakım düzenlemeler yapıp etkinliklerde bulunurlar 
(Malinowski, 1992, s. 35-36). İhtiyaçları karşılamak için zanaatlar ortaya çıkar, sonrasında insanların bir amacı gerçekleştirmesi ve herhangi bir sonuca varması için -Malinowski'nin "kurum (insanların bir araya gelmelerine neden olan birtakım geleneksel değerler üzerinde varılan bir antlaşma.)" olarak adlandırdığ1- örgütlenme oluşur. Toplumda bilgi birikimi sağlanır, ardından değerler ve ahlâk duygusu gelişir. Malinowski'ye göre işlev, kültürel yaratmaların bir toplumun ihtiyaçlarını iş birliği yaparken veya tüketim esnasında yapılan etkinliklerle karşılaması şeklinde tanımlanabilir (Çobanoğlu, 2019, s. 254).

Malinowski, "Bilimsel Bir Kültür Teorisi" adlı eserinde işlevselciliğin genel aksiyomlarını şöyle sıralar:

A. Kültür özünde araç olan bir aygıttır; insanlar, ihtiyaçlarını karşılamada ve problemlerinin çözümünde kültürden destek alırlar.

B. Kültür bir nesneler, eylemler ve zihniyetler sistemidir, bu sistem içerisinde her parça bir amaca hizmet eden bir araç olarak bulunur.

C. Kültür çeşitli unsurları karşılıklı birbirine bağlı olan bir bütündür.

D. Eylemler, önemli yaşamsal ödevler çevresinde kurumlar halinde örgütlenmiştir. Bu örgütlenmeler; ihtiyaç duyulan politik, ekonomik, hukuksal veya eğitsel etkinlikler için oluşmuş kurumlardır.

E. Etkinliğin türüne göre kültürde bazı yanlar ayırt edilir, sözgelimi eğitim, toplumsal denetim, ekonomi, bilgi sistemleri, ahlak ve inanç, yaratıcı ve sanatlı anlatım biçimleri gibi." (Malinowski, 1992: 21-22).

Antropolojik kuramcılar, halk kültürü yaratmalarının icra (performans) ve bağlam (icra edildiği ortam) çerçevesinde bir anlam ifade edebileceğini düşünürler. Bir halk edebiyatı yaratmasının ortaya çıkma, icracının onu ortaya koyma, dinleyicinin de sözlü metni anlama, öğrenme ve kullanma nedenleri değerlendirilmelidir.

\section{Bulgular}

Halk edebiyatı yaratmaları, insanların ortak kurdukları hayat düzenleri içerinde ortaya çıkmaktadır. Hayat düzeni içerisinde ortaya çıkan ihtiyaçlar ve toplumların bu ihtiyaçlar çerçevesinde ürettikleri halk edebiyatı ürünleri onların yaşam felsefelerini, üretim tüketim faaliyetlerini, toplumsal değerlerini, dil özelliklerini üzerlerinde taşırlar. İşlevsel kuram bakış açısına göre sosyal yaşamın içerisinden doğan halk edebiyatı yaratmaları ortaya çıktıkları sosyal çevre ve icra bağlamında incelenmelidir.

Halk edebiyatı yaratmalarının işlevleri konusunda araştırmalardan yararlanarak bir model oluşturan antropolog William R. Bascom'dur. Bascom'a göre halk edebiyatı ürünlerinin işlevleri en basit şekliyle şöyle sıralanabilir:

1. Eğlenme, Eğlendirme ve Hoşça Vakit Geçirme İşlevi

2. Toplumsal Kurumlara ve Törelere Destek Verme İşlevi

3. Eğitim ve Kültürün Genç Kuşaklara Aktarılması İşlevi

4. Toplumsal ve Kişisel Baskılardan Kurtulma İşlevi (Bascom, 2005, s. 125-151)

Aliağa Karaköy köyü yöresinden derlenen mâniler, Bascom'un halk edebiyatı ürünlerinin işlev özellikleri çerçevesinde değerlendirilecektir. 


\section{Eğlenme, Eğlendirme ve Hoşça Vakit Geçirme İşlevi}

Kaynak kişiler dinlendiğinde ve derlenen mânilerin geneli incelendiğinde mânilerin çoğunun eğlenme, eğlendirme ve hoşça vakit geçirme işleviyle söylediği görülmektedir. Yörede söylenen mânilerin çoğunun evlenme törenleri olarak ifade ettiğimiz nişan, düğün, kına gecesi, sünnet kutlamaları gibi nedenlerle bir araya gelen kadınların toplantılarında dümbek (darbuka) veya leğen gibi enstrümanları eğlence ortamlarını şenlendirme aracı olarak kullanıldığ 1 görülmektedir. Bu toplantılara erkeklerin katılmadığı, oynanan oyunların ve söylenen mânilerin katılımcı diğer kadın misafirlerle söylendiği öğrenilmiştir.

Söylenen mâniler genellikle ezgili bir şekilde oyun oynama etkinliği ile birlikte yapılmaktadır. Yörede mâni icrasına "mâni söyleme" "türkü söyleme" gibi isimler verilmektedir. Eğlenme eğlendirme ve hoşça vakit geçirme işleviyle ezgi eşliğinde söylenen mânilerden birkaçı şu şekildedir:

$\begin{array}{lll}\text { Karpuz kestim suyumuş } & \text { Bahçede kavak dalı } & \text { Şu derenin taşları } \\ \text { Yâr dizime uyumuş } & \text { Sevdiğim oğlan Ali } & \text { Cıvıl cıvıl kuşları } \\ \text { Ne diyelim sevdiğim } & \text { Ali benim olursa } & \text { Senin yârla benim yâr } \\ \text { Nasibimiz buyumuş (KK1) } & \text { N'olacak dünya malı (KK1) } & \text { Çoban arkadaşları (KK1) }\end{array}$

Mânilerin çeşitli söyleniş amaçlarından birisi dügün, nişan törenleri ve özel günlerde sevgi ve aşkı ifade etmektir (Ekici, 2002, s. 25). Halk bilgisi yaratmalarının icralarındaki temel işlev hoşça vakit geçirme gibi görünse de icralardaki tek işlev bu değildir, çoğu gülme unsurunun arkasında derin anlamlar bulunur (Ekici vd., 2018, s. 88). Yöre halkı söyledikleri sevda mânilerinde sevgi, hasret ve beddualarını dile getirmiş olup duygularını mânilerin eğlence, hoşça vakit geçirme işleviyle dışa vurmuşlardır.
Örün örün örenler
Entarisi ak gibi
Kara kara kazanlar
Bizi burada görenler
Suya gider ok gibi
Karayazı yazanlar
Aldı gitti yârimi
Hiç ardına bakmıyor
Cennet yüzü görmesin
Yanık sesli trenler (KK1)
Köyde yâri yok gibi (KK1)
Aramızı bozanlar (KK1)

Aliağa Karaköy yöresinde tarım ve hayvancılık ile uğraşan halkın yaşamında zeytin önemlidir. Zeytin toplama çalışmalarının zaman zaman imece usulüyle yapılması, halk edebiyatı yaratmalarına katkı sunan kültürel bir etkinliktir. Tarım ürünlerinden elde edilen gelirin çoğu zeytinden sağlanmaktadır. Zeytin ağaçlarının yaygın olduğu yörede ağacın dalları, yaprağı ve zeytin mânilerde çokça yer alır. Yörede çokça bulunan zeytin ve zeytin ile ilgili söylemlerin mânilerde yer alması halk edebiyatı yaratmalarına sosyal yaşamın etkisiyle ilgilidir.
Zeytin yaprağ 1 dökmez
Derelerde zeytinim
Zeytin yaprağ 1 yeşil
Muhabbet bizden gitmez
Babam yokta yetimim
Altında kahve pişir
İlk gözüm seni gördü
Askerdeki yârimi
Beni sana vermezler
Başkasını kâr etmez (KK1)
Telgrafla getirin (KK2)
Altında kahve pişir (KK1) 
Bununla birlikte yöre mânilerinde ilk dizlerde yer alan bitki türlerinden yöre iklimi ve tabiat ortamı ile ilgili bilgi edinmek mümkün olabilir. Özellikle hoş kokulu bir çiçek olan karanfilin yörede özel bir yeri vardır. Evlerin giriş kapısının sol kısmında yer alan sabit taşın üzerinde saksı içerisinde hoş kokulu karanfil yetiştirmenin yörede yaygın olduğu kaynak kişilerden öğrenilen bilgiler arasındadır. (KK2)

\begin{tabular}{|c|c|c|}
\hline Karanfil demet demet & Karanfilin alına & Karanfilim budama \\
\hline Sevdiğim oğlan Mehmet & Ölüyorum yoluna & Sefa geldin odama \\
\hline Mehmet benim olursa & Yirmi sene beklerim & Madem beni seviyon \\
\hline Dünya üstüme cennet (KK1) & Karagözlüm yoluna (KK1) & Dünür gönder babama (KK2) \\
\hline Bahçelerde muşmula & Gül kuruttum kalburda & Bahçelerde pıransa \\
\hline Yârin gönlü hoşmola & Keramet çok sabırda & Yaprağına kar yağsa \\
\hline Ben bir rüyalar gördüm & İkimiz bir ölelim & Oğlanlar bekâr kalsa \\
\hline Hayırmola düşmola (KK2) & Bir girelim tabuta (KK2) & Kizlara da yalvarsa (KK2) \\
\hline
\end{tabular}

\section{Toplumsal Kurumlara ve Törelere Destek Verme İşlevi}

İşlevsel çözümleme modeline göre folklorun işlevlerinden biri de kültürdeki ritüellerin, toplumsal kurumların (İnsanların bir araya gelmelerine neden olan birtakım geleneksel değerler üzerinde varılan bir antlaşma.) kültürü icra eden ve seyredenlerce doğrulanıp onaylamasıdır. Böylece toplumsal kurum ve değerlerin güncellenmesi, güçlenip kökleşmesi sağlanmış olur (Çobanoğlu, 2019, s, 263).

Yöreden derlenen mânilerde geleneklere ait değerler, bazı ritüeller ve toplumun benimseyip kabul ettiği kurallar nasihat şeklinde karşımıza çıkmaktadır.

Kızların ve erkeklerin kavuşmasının geleneğine vurgu yapılarak kavuşmanın ancak evlenmek yoluyla mümkün olacağının belirtildiği mânilere örnek verilebilir:
Hasır altı nem alır
Bahçelerde pitırak
Alime'yi kim alır?
Gel sevdiğim oturak
Alırsa Ali alır
Oturak da ne yapak
Almazsa bekâr kalır (KK1)
Evlenek de kurtulak (KK2)

Evli insanlara gönül verilmemesi gerektiğini ögütleyen, aile bütünlüğünü korumaya yönelik nasihat içeren mâni örneği ise şu şekildedir:

$$
\begin{aligned}
& \text { Hayıt dibi kum mudur? } \\
& \text { Yaprağ1 da su mudur? } \\
& \text { Evliye gönül verme } \\
& \text { Eve gider unutur (KK2) }
\end{aligned}
$$

Bazı mânilerde sevgilinin al bayraklı bir otobüsle gitmesinden bahsedilerek bir gurbet yolculuğuna dikkat çekilmiştir. Bu otobüs asker ocağının kutsallığını ifade eden bir kullanım da olabilir. Diğer mânide ise askerdeki yâr ile iletişim yöntemi işlenmiştir:

Tarlalarda patates Derelerde zeytinim 
Biz yemeyiz patates

Aldı gitti yârimi

Al bayraklı otobüs (KK2)
Babam yok da yetimim

Askerdeki yârimi

Telgırafla getirin (KK2)

Yöredeki insanların İslamiyet inancını güçlendirmek için uyulması gereken kurallar ile ilgili mâniler de şu şekildedir:
Hocanın adı hikmet
Bahçemizde oturak
Geceniz sabah olsun
Ardında getir kamet
Yanında yeşil yaprak
Dualar kabul olsun
Peygambere ümmet ol
Dünyaya meyil etme
Beş vakit kıl namazı
Ardından gelir cennet (KK3)
Sonundur kara toprak (KK2) Mekânın cennet olsun (KK2)

\section{Eğitim ve Kültürün Genç Kuşaklara Aktarılması İşlevi}

Folklorun bu üçüncü işlevine göre, sadece sözlü kültür geleneği olan toplumlarda folklorun taşıdığ $\breve{1}$ bilgiler tarihsel olarak gerçek ve öğretimleri son derece önemli olarak kabul edilir. Bu bağlamda folklor, kültürün aynası ve kılavuz olarak düşünülmektedir (Çobanoğlu, 2019, s. 263).

Derleme alanı olan Aliağa Karaköy yöresinde sözlü kültürün eğitici etkisi ve yöre kültürünün genç kuşaklara aktarılmaya çalışıldığı mâni örneklerine rastlanmaktadır.

Mâni bilmenin ve söylemenin önemini vurgulayan mâni örneği şu şekildedir:

$$
\begin{aligned}
& \text { Mâniye maraz derler } \\
& \text { Güzele beyaz derler } \\
& \text { Mâni bilmeyenlere } \\
& \text { Çöplükte horoz derler (KK2) }
\end{aligned}
$$

Bilgili olmanın iyiliği cehaletin kötülüğünü vurgulayarak tahsilli insanın kıymetini ön plana çıkaran mâni örneği şu şekildedir:
Tarladan kaçana bak
Kuyudan geçene bak
Cahille sevda olmaz
Okuyan yazana bak (KK2)

Toplum, aile yapısı içerisinde anne babanın sözünün değerini ve önemini aktaran mâni örneği şu şekildedir:

Şu direğe çıkmalı

Deryalara bakmalı

Ana baba sözünü

Akıllarda tutmalı (KK3) 


\section{Toplumsal ve Kişisel Baskılardan Kurtulma İşlevi}

Toplumsal ve kişisel baskılardan kurtulma işlevi açık olmamakla birlikte işlevsel kuramın psikanalist kuramla birleştiği madde olarak görülebilir. Toplum tarafından yasaklanmış bazı söz, düşünce ve davranışların halk edebiyatı yaratmalarında ifade edilmesi olarak açılanabilecek bu işlev toplumsal ve kişisel baskılardan kurtulma işlevi olarak da değerlendirilebilir. Toplumun kabul etmediği davranışların veya düşüncelerin mâni veya türkülerde yer alması halk yaratmasının bu işlevi yerine getirmesidir (Ekici vd., 2018, s. 89).

Evlenmeden bir araya gelme toplumun hoş karşılamadığı bir durumdur. Bu durum, birbirine kavuşmayı arzu eden kişiler için baskı unsurudur. Folklorun toplumsal ve kişisel baskılardan kurtulma işlevi yöreden derlenen bazı mâni örneklerinde şu şekilde dile getirilmiştir:

Bahçelerde gül var mı?

Gül dibinde yol var mı?

Akşam yanına varırsam

Karyolada yer var mi? (KK1)

Ailenin onay vermediği bir evlilik isteğinin gerçekleşmesi için yapılan kaçma ve buluşma planları da yine mânilerde şu şekilde dile getirilmiştir:
Ağaçlarda kumru
Karşı karşı duralım
Ayakları yumulu
Telefonu kıralım
Havva'yla Kâzım kaçmış
Telefonla iş olmaz
O da kimin umuru (KK2)
Gel yârim buluşalım (KK1)

W. Bascom'un yukarıdaki folklor işlevlerine ek olarak bir de protesto işlevinden söz edilmektedir. Marksist ideolojiye mensup halk bilimciler tarafından eklenen bu işlev, zenginfakir, yönetici-yönetilen arasındaki sınıf mücadelesi çerçevesindeki sınıf çatışmaları sebebiyle yaşanan hak mücadelesinin halk yaratmalarına yansıtılmasıdır (Başgöz, 1996, s. 1-4).

\section{Tartışma, Sonuç ve Öneriler}

İzmir Aliağa Karaköy köyü yöresinde yaşayan kaynak kişilerden derlenen mâniler incelendiğinde geçmişten bugüne halkın yaşantısını içerisinde barındırarak bugünlere gelmiş olan mânilerin İzmir Aliağa Karaköy köyü yöresinde de yaşamın içerisindeki canlı bir edebî tür olarak yer almış olduğu anlaşılmaktadır. Yörede daha çok kadınlar tarafından darbuka veya leğen çalınarak daha çok ezgi eşliğinde yürütülen mâni söyleme etkinliğinin "türkü söyleme" olarak da adlandırıldığı öğrenilmiştir. Üç kaynak kişiden derlenen altmış mâninin yöre insanının yaşam biçimi, dil özellikleri, folklorik uygulamaları, değer ve inanışları gibi kültürel unsurlarını birçok yönüyle içerisinde barındırdığının tespit edilmiş olması mânilerin kültürel unsurları taşıma aktarma işlevine örnek teşkil etmektedir.

Ardında insan ve toplumların temel ihtiyaçlarının yer aldığı kültürel yaratmalar, bir toplumun ihtiyaçlarını iş birliği yaparken veya tüketim esnasında yapılan etkinliklerle bir işlevi yerine getirirler. Yaşam serüvenleri içerisinde birçok faaliyette bulunma ihtiyacı hissederler. İşlevsel halk bilimi kuramına göre evlenme törenleri, Nevruz, Hıdırellez kutlamaları, imece toplantıları ihtiyaçtan doğan bir işlevi yerine getirmek için yapılan uygulamalardır. $\mathrm{Bu}$ 
faaliyetler, Malinowski'nin kurum olarak adlandırdığ geleneksel değerler üzerinde bir anlaşma sağlamak amacıyla düzenlenir.

William R. Bascom'un, folklor unsurlarının işlevsel özellikleri yaklaşımına göre değerlendirilen Aliağa Karaköy yöresi mânilerinin büyük oranda eğlenme, eğlendirme ve hoşça vakit geçirme işlevini yerine getirdiği tespit edilmiştir. Evlenme törenleri, kutlamalar, kadınlar arsında tertiplenen ev buluşmaları ve dayanışma faaliyetleri çerçevesinde söylenen mâniler her ne kadar eğlenme ve hoşça vakit geçirme işlevini karşılasa da bu yaratmaların aslında arka planda insanların içlerindekini dişa vurma ve kendilerini ifade etme işleviyle ortaya çıktığı söylenebilir. Yörede az da olsa yaşayan mâni söyleme uygulamasının kültürü icra eden kişilere itibar, saygınlık da kazandırma, onları sosyal hayata adapte etme işlevinin de olduğu söylenebilir.

Derlenen mânilerden bazılarının İslâm inanç ve değerleri, aile ve evlilik kurumu, toplumsal dayanışma gibi konulara yer vermesi, mânilerin icrası ve sunuluşu, kutlamalar esnasında yapılan uygulamalar; yöreden derlenen mânilerin toplumsal kurumlara ve törelere destek verme işlevi ekseninde değerlendirilebilir.

Bize göre mânilerin tamamını halk kültürü yaratmalarının eğitim ve kültürün genç kuşaklara aktarılması işlevi ile ilişkilendirmek gerekir. Çoğunun doğrudan olmasa da dolaylı olarak eğitim ve aktarama işlevi olduğu aşikârdır. Derlenen mânilerden bazılarında tespit edilen anne babaya saygı, cehalete karşı bilgeliğin önemi gibi eğitim ve aktarmaya doğrudan yapılan işaretlerden de söz etmek gerekir.

Bazı mânilerde ifade edilen evlenmeden bir araya gelme, aile onayının olmadığı evlilikler için kaçma ve buluşma planları yöreden derlenen mânilerde yer alan konular arasındadır. Bu mâni metinlerinin Bascom'un sözlü halk edebiyatı yaratmalarının halk kültüründeki işlevlerinden toplumsal ve kişisel baskılardan kurtulma işlevini karşıladıkları anlaşılmaktadır.

İşlevsel halk bilimi kuramı çerçevesinde değerlendirilen İzmir Aliağa Karaköy yöresi mânilerinin kuramın temsilcilerinden Bascom'un sıraladığ 1 folklorun dört işlevini karşıladığ1 söylenebilir. Mâniler, yörede insanların birikim ve yeteneklerini ortaya koyarak sözlü geleneğin imkânlarıyla eğlendikleri, hoşça vakit geçirdikleri ortamlarda söylenegelmiştir.

Aliağa Karaköy yöresinde, mânilerin yoğun biçimde söylendiği sosyal ortamların kent kültürünün etkisi, dijitalleşme ve sosyoekonomik sebeplerle değiştiği; dolayısıyla mâni söyleme kültürünün yaşam şartlarının değişmesiyle gitgide zayıfladığı tespit edilmiştir. Mâni söyleme uygulamasının daha çok yaşlılar tarafından bilindiği, bu yüzden geleneğin kısmen sürdürüldügünü belirtmek gerekir. Mâni söyleme gibi kültürel zenginliğin taşıyıcısı olan sözlü edebiyat geleneklerinin gençlere aktarılması için projeler geliştirilmelidir. 


\section{Yöreden Derlenen Diğer Mâniler}

\begin{tabular}{|c|c|c|}
\hline $\begin{array}{l}\text { Ayakkabım toz atar } \\
\text { Oğlan bana göz atar } \\
\text { Atma oğlan şu gözü } \\
\text { Elalem bize bakar (KK1) }\end{array}$ & $\begin{array}{l}\text { Entarisi ak gibi } \\
\text { Yolda gider ok gibi } \\
\text { Hiç ardına bakmıyor } \\
\text { Köyde yâri yok gibi (KK1) }\end{array}$ & $\begin{array}{l}\text { Allar giymiş boyunca } \\
\text { Göremedim doyunca } \\
\text { Ben aklımı şaşırdım } \\
\text { Yâri asker duyunca (KK1) }\end{array}$ \\
\hline $\begin{array}{l}\text { Ceketi var kısacık } \\
\text { Ucundan eklenecek } \\
\text { Nerden geçecen yârim? } \\
\text { Yolların gözlenecek (KK1) }\end{array}$ & $\begin{array}{l}\text { Ceviz aldım yüz dirhem } \\
\text { Kaştır gözü süzdüren } \\
\text { Senin aşkın değil mi? } \\
\text { Beni berduş gezdiren (KK1) }\end{array}$ & $\begin{array}{l}\text { Kamyondan inemedim } \\
\text { Taksiye binemedim } \\
\text { Yedi saat konuştum } \\
\text { Bir cevap veremedim (KK1) }\end{array}$ \\
\hline $\begin{array}{l}\text { Bahçede kavak dalı } \\
\text { Sevdiğim oğlan Ali } \\
\text { Ali benim olursa } \\
\text { N'olacak dünya malı (KK1) }\end{array}$ & $\begin{array}{l}\text { Karanfil demet demet } \\
\text { Sevdiğim oğlan Mehmet } \\
\text { Mehmet benim olursa } \\
\text { Dünya üstüme cennet (KK1) }\end{array}$ & $\begin{array}{l}\text { Zeytin yaprağı dökmez } \\
\text { Muhabbet bizden gitmez } \\
\text { İlk gözüm seni gördü } \\
\text { Başkasını kâr etmez (KK1) }\end{array}$ \\
\hline $\begin{array}{l}\text { Mektup yazdım köşeli } \\
\text { İçi destan döşeli } \\
\text { Hiç haberini almadım } \\
\text { İstanbul'a düşeli (KK1) }\end{array}$ & $\begin{array}{l}\text { Giden oğlan dursana } \\
\text { Saatini kursana } \\
\text { Madem beni seviyon } \\
\text { Anneni kandırsana (KK1) }\end{array}$ & $\begin{array}{l}\text { Karşı karşı hanımız } \\
\text { Çarşıda harmanımız } \\
\text { Sen ordan çık ben burdan } \\
\text { Çatlasın düşmanımız (KK1) }\end{array}$ \\
\hline $\begin{array}{l}\text { Kabağın kökeniyim } \\
\text { Dibinin dikeniyim } \\
\text { Ben güzel alacağım } \\
\text { Çirkine tövbeliyim (KK1) }\end{array}$ & $\begin{array}{l}\text { Söğütteki kuşa bak } \\
\text { Gözümdeki yaşa bak } \\
\text { Bu sene vaktimiz yok } \\
\text { Yeni seneye kışa bak (KK1) }\end{array}$ & $\begin{array}{l}\text { Ayağ1 mesli yârim } \\
\text { Güvercin sesli yârim } \\
\text { Ordan geçme burdan geç } \\
\text { On dile saçlı saçlı yârim (KK1) }\end{array}$ \\
\hline $\begin{array}{l}\text { Entarim dutlu dutlu } \\
\text { Bugün hava bulutlu } \\
\text { Ben yârimi görmedim } \\
\text { Görenlere ne mutlu (KK1) }\end{array}$ & $\begin{array}{l}\text { Tarlalarda ayrık var } \\
\text { Deryalarda balık var } \\
\text { Şimdi buradan geçti } \\
\text { Omzunda yağlık var (KK3) }\end{array}$ & $\begin{array}{l}\text { Narinimin tekini } \\
\text { Ben sevdim seninkini } \\
\text { Bundan sonra dönmek yok } \\
\text { Sen de sev benimkini (KK3) }\end{array}$ \\
\hline $\begin{array}{l}\text { Gemi gelir balçıktan } \\
\text { Balık yenmez kılçıtan } \\
\text { Bizim köyün kızları } \\
\text { Görünmüyor boncuktan (KK2) }\end{array}$ & $\begin{array}{l}\text { İki tabakta pekmez } \\
\text { Biri birine akmaz } \\
\text { Senin bana yaptığını } \\
\text { Yunan gâvırı yapmaz (KK2) }\end{array}$ & $\begin{array}{l}\text { Merdivenim kırkayak } \\
\text { Kırkına vurdum dayak } \\
\text { Yârin gelmiş dediler } \\
\text { Seyirttim yalınayak (KK2) }\end{array}$ \\
\hline $\begin{array}{l}\text { Kız: } \\
\text { Sayamın tuğlasını belime sardım } \\
\text { Kırmızı bohçamı elime aldım } \\
\text { Kalk gidelim emmimoğlu } \\
\text { Sana diye geldim } \\
\text { Erkek: } \\
\text { Kırmızı buğdaylarım saçıldı } \\
\text { kaldı } \\
\text { Sarı öküzlerim koşulu kaldı } \\
\text { Nasıl gelem emmim kızı? }\end{array}$ & $\begin{array}{l}\text { Pınara varmadın mı? } \\
\text { Gül koydum almadın mı? } \\
\text { Seni zalımın kızı } \\
\text { Hiç beni anmadın mı? (KK1) } \\
\text { Göz göze bakışalım }\end{array}$ & $\begin{array}{l}\text { Kahvenin biçtiği eller } \\
\text { Pişip taştığ eller } \\
\text { Güzel çirkin demiyor } \\
\text { Sevdanın düştüğü eller (KK1) }\end{array}$ \\
\hline
\end{tabular}




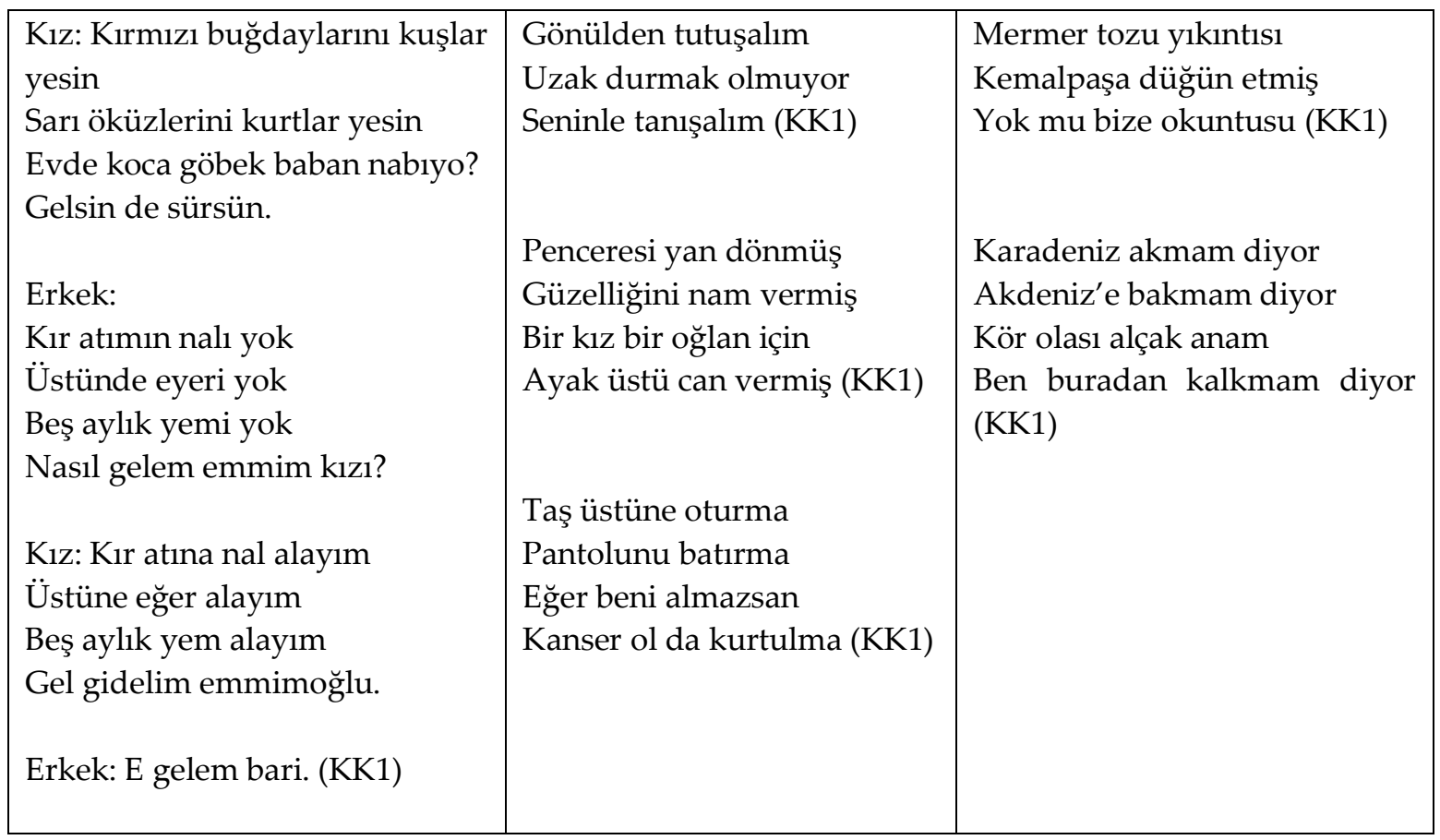

\section{Teşekkür ve Bilgilendirme}

Araştırma çalışması sürecindeki desteklerinden dolayı sevgili dostum Cahit Türk ve değerli öğrencim Emine Algül'e teşekkür ederim.

\section{Kaynakça}

\section{Yazılı Kaynaklar}

Artun, E. (2006). Türk Kültüründe Mâni Söyleme Geleneği, Mânilerin İletişim Boyutu ve İşlevselliği, Erişim adresi: http://www.turkoloji.cukurova.edu.tr/

Bascom, William R. (2005). Folklorun Dört İşlevi. (Çeviren: Ferya Çalış). Halkbiliminde Kuramlar ve Yaklaşımlar 2. (Editör: M. Öcal Oğuz ve Selcan Gürçayır). Ankara: Geleneksel Yayınları

Başgöz, İ. (1996). Protesto: Folklorun Beşinci İşlevi (Fonksiyonu). Folkloristik: Umay Günay Armağanı, Haz.: Özkul Çobanoğlu-Metin Özarslan. Ankara: Feryal Matbaası

Boratav, P. N. (1995). 100 Soruda Türk Halk Edebiyatı, İstanbul: Gerçek Yayınları

Çobanoğlu, Ö. (2019). Halk Bilimi Kuramları ve Araştırma Yöntemleri Tarihine Giriş. Ankara: Akçağ Yayınları

Dilçin, C. (1995). Örneklerle Türk Şiir Bilgisi. 3.bs., Ankara: TDK Yayınları

Ekici, M. (2002). “Ödemiş Yöresi Mânileri Üzerine Bir Değerlendirme” Motif Dergisi, S. 31.

Ekici, M. (2004). Halk Bilgisi (Folklor) Derleme ve İnceleme Yöntemleri. Ankara: Geleneksel Yayınları 
Ekici, M.- Oğuz, Ö.- Aça, M. ve Diğerleri (2018). Türk Halk Edebiyatı El Kitabı. Ankara: Grafiker Yayınları

Elçin, Ş. (1997). Halk Edebiyatı Araştırmaları, Ankara: Akçă̆ Yayınları

Güvenç, B. (2002). İnsan ve Kültür. İstanbul: Remzi Kitabevi

Karabaş, Seyfi (1981). Bütüncül Türk Budunbilimine Doğru. Ankara: ODTÜ Yayınları

Malinowski, B. (1992). Bilimsel Bir Kültür Teorisi. (Çev.: S. Özkal), İstanbul: Kabalcı Yayınları

Şimşek, E., (2015). “Anonim halk şiiri içerisinde mânilerin yeri" Akra Kültür Sanat ve Edebiyat Dergisi, S.5

\section{Sözlü Kaynaklar}

K.K.1 Sultan Kara, 1941, Aliağa, Evli, İlkokul mezunu, Ev hanımı, Görüşme tarihi: 01.02.2021

K.K.2 Hacı Medeni Saftekin, 1945, Aliağa, Evli, İlkokul mezunu, Ev hanımı, Görüşme tarihi: 03.02.2021

K.K.3 Server Çebiç, 1961, Aliağa, Evli, İlkokul mezunu, Ev hanımı, Görüşme tarihi: 05.02.2021 